\title{
STUDIES OF GLYCOGEN METABOLISM IN LIVER GLYCOGEN DISEASE (VON GIERKE'S DISEASE) : SIX CASES WITH SIMILAR METABOLIC ABNORMALITIES AND RESPONSES TO GLUCAGON *
}

\author{
By JOSEPH E. SOKAL, CHARLES U. LOWE, EDWARD J. SARCIONE, LUIS L. \\ MOSOVICH AND BERNARD H. DORAY WITH THE TECHNICAL \\ ASSISTANCE OF SYLVIA FLEISSNER AND JOYCE GOLDSTEIN \\ (From the Division of Medicine, Roswell Park Memorial Institute and the Statler Research \\ Laboratories of the Children's Hospital and the Department of Pediatrics, \\ The University of Buffalo School of Medicine, Buffalo, N. Y.)
}

(Submitted for publication July 8, 1960 ; accepted October 20, 1960)

Glycogen disease of the liver (von Gierke's disease) is a rare and incompletely understood disorder of childhood. It is characterized by defective breakdown of liver glycogen to glucose. In most cases, excessive liver glycogen deposition occurs, reaching levels as high as 14 to 17 per cent of the wet liver weight $(1,2)$. Major clinical manifestations include hepatomegaly; fasting hypoglycemia, acidosis and ketosis; delayed growth and development, and increased morbidity with even minor infections. The most severely affected children have usually died during infancy. Histologic studies of autopsy or biopsy specimens of liver reveal essentially normal architecture, but hepatic cells contain excessive amounts of glycogen and often, fat. The glycogen is usually normal in structure (3) and can be broken down to glucose by homogenates of normal animal or human liver $(2,4,5)$. Spontaneous breakdown of glycogen during in vitro incubation of liver tissue from affected children is deficient $(2,4,6)$.

The currently accepted pathways of liver glycogen metabolism are summarized in Figure 1. It was formerly believed that glycogen was synthesized through the action of phosphorylase, the same enzyme that catalyzes its breakdown. However, it is now agreed that this reaction, which occurs readily in vitro, is not an important one in vivo (7), and that glycogen synthesis probably proceeds through the uridine-diphosphoglucose pathway described by Leloir and Cardini (8). Glycogen breakdown is mediated by phosphorylase

* Supported in part by a research grant (A-1646) from the National Institute of Arthritis and Metabolic Diseases, Bethesda, Md., and by a grant from Eli Lilly and Co. Presented (in part) at the Fifty-first Annual Meeting of the American Society for Clinical Investigation, May 4, 1959, Atlantic City, N. J. and amylo-1,6-glucosidase ("debrancher enzyme"), with glucose-1-phosphate as the principal product. This is converted to glucose-6-phosphate in a reversible reaction catalyzed by phosphoglucomutase. Glucose is liberated from this intermediate by glucose-6-phosphatase. Small amounts of glucose are also formed directly from glycogen through the action of amylo-1,6-glucosidase at branch points in the glycogen molecule. Other metabolic pathways open to glucose-6-phosphate are partial oxidative degradation through the "hexose monophosphate shunt" and breakdown to pyruvate and lactate via the glycolytic pathway.

Intensive biochemical studies by several investigators have led to the subclassification of hepatic glycogen disease into several types, based on determination of the activity of certain hepatic enzymes. The clinical syndrome described above has been seen in association with deficiencies of glucose-6-phosphatase, amylo-1,6-glucosidase, or phosphorylase $(9,10)$. More recently, Hers reported a case which did not have a deficiency of any of these enzymes (11). Thus the problems of the fundamental pathophysiology and the subclassification of this syndrome are not yet completely resolved. However, all cases share a basic functional abnormality-defective breakdown of liver glycogen to glucose.

The clinical test most commonly employed in the diagnosis of hepatic glycogen disease consists of observation of the blood glucose response to injection of epinephrine or glucagon. Normal children or adults respond to these agents with a prompt elevation of the blood glucose level. $\mathrm{Pa}-$ tients with liver glycogen disease, on the other hand, show no response or only small and delayed increases in blood glucose concentration $(1,2,5$, 


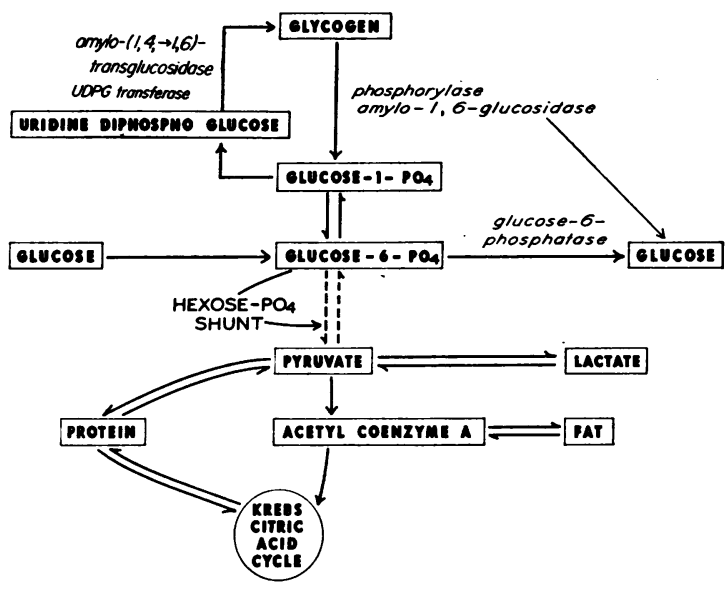

Fig. 1. Currently accepted pathways of liver glyCOGEN SYNTHESIS AND BREAKDOWN.

12-14). This has been considered as evidence that these hormones are ineffective or, at best, only partially effective in inducing hepatic glycogenolysis in this disease.

In the course of studies of glycogen deposition diseases, we have encountered six cases of liver glycogen disease with similar metabolic abnormalities and responses to glucagon. Observations in one of these cases (J.B.) were reported previously (15). The studies described below suggest that hepatic glycogenolysis occurred spontaneously in these patients in response to hypo- glycemia and that injections of glucagon induced rapid breakdown of liver glycogen. However, the principal end-product of hepatic glycogenolysis appeared to be lactate rather than glucose.

\section{METHODS AND CLINICAL MATERIAL}

Glucose was determined by the Nelson method (16). Lactate was determined by the Barker-Summerson method (17) and by an enzymatic method using lactic dehydrogenase (18). Both procedures gave similar results, but since the latter is more specific and proved to be convenient and dependable, it was used for most of the determinations. Glycogen was determined by the method of Good, Kramer and Somogyi (19), using the Nelson technique for the determination of glucose after hydrolysis.

None of the cases under study showed evidence of heart disease, skeletal myopathy or cirrhosis of the liver. Their principal diagnostic features are presented in Table I. Additional details will be reported elsewhere (20). Brief clinical summaries follow.

Patient 1. J.B. was a 10 month old white male infant admitted for investigation of an enlarged liver and episodes of vomiting and irritability. Two older siblings had died in infancy with enlarged livers, and the diagnosis of hepatic glycogen disease had been established in one of them. Hepatic enlargement had been noticed during the first few months of the patient's life and had increased progressively until admission. The infant developed hypoglycemia, acidosis and ketosis rapidly on fasting. Blood glucose values as low as 10 to 16 $\mathrm{mg}$ per $100 \mathrm{ml}$ were repeatedly obtained after 4 to 5 hours of fasting. Injection of epinephrine or glucagon

TABLE I

Principal diagnostic features of patients under study

\begin{tabular}{|c|c|c|c|c|c|c|}
\hline Patient & $\begin{array}{c}\text { Liver } \\
\text { glycogen }\end{array}$ & $\begin{array}{c}\text { Muscle } \\
\text { glycogen }\end{array}$ & $\begin{array}{l}\text { Liver* } \\
\text { phos- } \\
\text { phorylase }\end{array}$ & $\begin{array}{l}\text { Liver* } \\
\text { glucose-6-phos- } \\
\text { phatase }\end{array}$ & $\begin{array}{c}\text { Fasting } \\
\text { hypoglycemia }\end{array}$ & Remarks \\
\hline & $\%$ & $\%$ & \multicolumn{2}{|c|}{ imoles $P / g / 30 \mathrm{~min}$} & & \\
\hline 1 & 8.6 & 0.19 & 418 & 267 & Severe & $\begin{array}{l}\text { Liver and muscle incubation } \\
\text { results presented in Table II }\end{array}$ \\
\hline 2 & 10.2 & 1.48 & 56 & 9 & $\begin{array}{l}\text { Moderate to } \\
\text { severe }\end{array}$ & $\begin{array}{l}\text { Incubation of isolated glycogen } \\
\text { with purified phosphorylase } \\
\text { resulted in 30\% degradation }\end{array}$ \\
\hline 3 & & & & & $\begin{array}{l}\text { Moderate to } \\
\text { severe }\end{array}$ & Liver biopsy not performed \\
\hline 4 & $9.5 \dagger$ & & & & Mild & $\begin{array}{l}\text { Liver glycogen } 8.9 \% \text { after } 24 \\
\text { hours at room temperature }\end{array}$ \\
\hline 5 & $7.8 \ddagger$ & & & $\begin{array}{l}\text { Less than } 10 \% \\
\text { of normalf }\end{array}$ & Severe & \\
\hline 6 & 7.1 & 0.38 & 489 & 0 & Severe & $\begin{array}{l}\text { See text for liver incubation } \\
\text { results }\end{array}$ \\
\hline
\end{tabular}

${ }^{*}$ Method of Cahill, G. F., Zottu, S. and Earle, A. S. Endocrinology 1957, 60, 265. Normal values in our laboratory for human (adult) liver obtained at surgical biopsy are: phosphorylase, 200 to 500; glucose-6-phosphatase, 150 to 300.

$\dagger$ Personal communication, Dr. Harry W. Bain, Toronto.

$\$$ Reference 13 . 
produced slight or no rise in the blood glucose level. $\mathrm{He}$ had hyperlipemia. Laparotomy, and liver and muscle biopsy were performed. Histologic diagnosis was liver glycogen disease. Liver glycogen concentration was 8.6 per cent.

Patient 2. S. J. was a 2 year old white female infant admitted for investigation of a greatly enlarged liver. An enlarged abdomen was noted soon after birth. There was no familial history of glycogen disease. Moderate to severe hypoglycemia was noted after overnight fasting; on two occasions values below $20 \mathrm{mg}$ per $100 \mathrm{ml}$ were recorded. Mild acidosis and ketosis developed during fasting. Subcutaneous injection of epinephrine resulted in little or no rise of blood glucose (maximal increase, $16 \mathrm{mg}$ per $100 \mathrm{ml}$ ). Injection of glucagon resulted in small and delayed rises in blood glucose. She had moderate hyperlipemia. Laparotomy, and liver and muscle biopsy were performed. Histologic diagnosis was liver glycogen disease. Liver glycogen concentration was 10.2 per cent.

Patient 3. Jay F. was a 6 year old white female admitted with the diagnosis of hepatic glycogen disease. An older sibling (Patient 4) also had the disease. Enlargement of the abdomen had been noticed at the age of 4 months, and increasing hepatomegaly was recorded from the age of 7 months. The patient's growth was retarded but her mental development was normal. She had been maintained in relatively good condition by very frequent feedings. However, her course was marked by episodes of infection, acidosis, and severe epistaxis. She was an abnormally small child for her age, with a greatly enlarged liver. She developed moderate to severe hypoglycemia on fasting, with blood glucose levels falling as low as $17 \mathrm{mg}$ per $100 \mathrm{ml}$. Injection of epinephrine produced an insignificant rise in the blood glucose concentration. Injection of glucagon resulted in a small and delayed rise in the blood glucose level. Liver and muscle biopsies were not performed.

Patient 4. Jill F. was a 12 year old white female, the older sister of Patient 3. The diagnosis of hepatic glycogen disease had been established at the age of 17 months by clinical studies and liver biopsy. Injection of epinephrine resulted in a maximal rise of $12 \mathrm{mg}$ per $100 \mathrm{ml}$ in the blood glucose concentration. Histologic diagnosis was liver glycogen disease. Liver glycogen concentration was 9.5 per cent; there was only slight glycogenolysis in the biopsy specimen during 24 hours at room temperature. Her course since then has been characterized by frequent infections, bouts of acidosis, severe epistaxes and greatly retarded growth. Mental development was normal. She had a huge abdomen with massive hepatomegaly.

Patient 5. J.K. was a 6 year old white male. The diagnosis of liver glycogen disease had been established in the immediate neonatal period, when he was found to have hepatomegaly, severe hypoglycemia and acidosis. Intensive studies at that time (13), including liver biopsy, revealed the following. Moderate fasting induced severe hypoglycemia and acidosis, with occasional convulsions. There was little or no rise in blood glucose after injection of epinephrine or glucagon. Liver gly- cogen concentration was 7.8 per cent and hepatic glucose-6-phosphatase was greatly reduced. Histologic diagnosis was liver glycogen disease. One sibling had died in infancy of liver glycogen disease. The child's course since infancy was characterized by occasional episodes of severe hypoglycemia (despite a regimen of frequent feedings), hyperlipemia and xanthomata, and delayed growth. Mental development was normal. $\mathrm{He}$ was an abnormally small child (bone age 3.25 years) with a protuberant abdomen and a greatly enlarged liver.

Patient 6. M.M. was a 1 year old white female infant admitted with the diagnosis of liver glycogen disease. At 2 days of age she had been found to have hepatomegaly and a blood glucose level of $2 \mathrm{mg}$ per 100 $\mathrm{ml}$. Liver biopsy at 5 days of age revealed a histologic appearance typical of liver glycogen disease (no chemical determination of glycogen content). She was a small, weak infant, with a greatly enlarged liver, who developed severe hypoglycemia after 4 hours of fasting. Bone age was 6 months. There was virtually no rise in blood glucose concentration after glucagon injection. She had hyperlipemia. Repeat liver biopsy revealed a glycogen concentration of 7.1 per cent.

\section{RESULTS}

In vitro incubation studies. After the completion of preliminary clinical studies, laparotomy was performed in Patient 1. This patient, who tolerated fasting very poorly, received a slow infusion of glucose during the night before surgery. At laparotomy a piece of liver and a small sample of rectus muscle were obtained for in vitro study. The specimens were chilled rapidly and transported to the laboratory under refrigeration. Tissue slices were cut as rapidly as possible and added to flasks containing Krebs-Ringer phos-

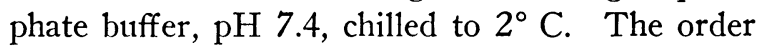
of slices entering the duplicate incubation flasks was such that no systematic effect attributable to the time of slicing would occur; i.e., the pattern used was $a b \ldots$ ba rather than aabb ... A A liver sample was withdrawn midway through the slicing procedure for determination of the initial glycogen concentration. Refrigeration of the incubation flasks was continued until slicing was completed. All flasks were then placed in a Dubnoff shaker-incubator and incubated for 2 hours at $37^{\circ} \mathrm{C}$ under a continuous flow of oxygen.

Liver slices were incubated in buffer alone and with several additives. At the end of 2 hours, an aliquot was withdrawn from each flask for glucose determination, 30 per cent potassium hydroxide was added to the incubation flasks, and glycogen 
TABLE II

Results of in vitro liver slice incubations, (Patient 1)

\begin{tabular}{|c|c|c|c|c|}
\hline $\begin{array}{l}\text { Wt of } \\
\text { slices }\end{array}$ & Type of incubation* & $\begin{array}{l}\text { Glyco- } \\
\text { gen }\end{array}$ & $\begin{array}{l}\text { Glyco- } \\
\text { gen } \\
\text { de- } \\
\text { crease }\end{array}$ & $\begin{array}{c}\text { Glu- } \\
\text { cose } \\
\text { re- } \\
\text { covered }\end{array}$ \\
\hline$m g$ & & \multicolumn{3}{|c|}{ mg glucose/g tissue } \\
\hline 153 & $\begin{array}{l}\text { Not incubated; } \\
\text { initial glycogen }\end{array}$ & 86 & & \\
\hline $\begin{array}{l}176 \\
137\end{array}$ & $\begin{array}{l}\text { After incubation; } \\
\text { without additives }\end{array}$ & $\begin{array}{l}79 \\
79\end{array}$ & $\begin{array}{l}7 \\
7\end{array}$ & $\begin{array}{l}\mathbf{0} \\
\mathbf{0}\end{array}$ \\
\hline $\begin{array}{r}165 \\
90\end{array}$ & $\begin{array}{l}\text { After incubation with } \\
50 \mu \mathrm{g} \text { glucagon/flask }\end{array}$ & $\begin{array}{l}64 \\
48\end{array}$ & $\begin{array}{l}22 \\
38\end{array}$ & $\begin{array}{r}4 \\
10\end{array}$ \\
\hline $\begin{array}{l}162 \\
190\end{array}$ & $\begin{array}{l}\text { After incubation with } \\
\text { rat liver homogenate } \dagger\end{array}$ & $\begin{array}{l}58 \\
60\end{array}$ & $\begin{array}{l}28 \\
26\end{array}$ & $\begin{array}{l}27 \\
29\end{array}$ \\
\hline
\end{tabular}

* All incubations conducted in $3 \mathrm{ml} \mathrm{Krebs-Ringer} \mathrm{phosphate} \mathrm{buffe}$ containing additives as described.

$\dagger$ Each flask contained $638 \mathrm{mg}$ of rat liver homogenized in buffer The results shown are after correction for incubated rat liver blanks which were: glycogen 0,0 ; glucose $4.9,4.7 \mathrm{mg}$ per $\mathrm{g}$.

determination was performed. Muscle slices were incubated in Krebs-Ringer phosphate buffer without additives.

Table II presents the results of liver slice incubations without additives, with glucagon, and with a homogenate of liver obtained from a fasted normal rat. The initial liver glycogen concentration was $86 \mathrm{mg}$ per $\mathrm{g}$. Slices incubated without additives showed only a slight decline in glycogen content during incubation and no glucose production. Unequivocal stimulation of glycogenolysis was induced by glucagon. However, only small amounts of glucose appeared in the incubation medium. Incubation with rat liver homogenate, on the other hand, resulted in the production of glucose in amounts corresponding to the loss of glycogen.

In contrast to the defective glycogenolysis observed during incubation of liver slices, normal glycogen breakdown was observed during incubation of muscle. The initial muscle glycogen concentration was $1.9 \mathrm{mg}$ per $\mathrm{g}$, a relatively low value. After incubation it was $0.3 \mathrm{mg}$ per $\mathrm{g}$.

The failure to account for the products of glycogenolysis during incubation of liver slices was not anticipated and did not become known in time to permit analyses for other possible metabolites of glycogen. However, material from another incubation experiment, performed at the same time, was available. Liver slices had been incubated with $\mathrm{C}^{14}$-glucose, without hormonal additives. The flask contents had been frozen and stored for later study. This material was thawed and analyzed for glycogen, glucose and lactate. The amount of glucose recovered was $0.59 \mathrm{mg}$ per flask, virtually the same as the amount added$0.54 \mathrm{mg}$. Glycogen concentration was $68 \mathrm{mg}$ per $\mathrm{g}$, indicating breakdown of $18 \mathrm{mg}$ per $\mathrm{g}$, more than was observed in the control incubations shown in Table II. The amount of lactate recovered was equivalent to $21 \mathrm{mg}$ per $\mathrm{g}$ of liver. Determination of radioactivity demonstrated that very little of this lactate could have been derived from the added glucose. Although the original concentration of lactate in this liver specimen had not been determined, it is most unlikely that it could have been high enough to account for the amount recovered (about 2,600 $\mathrm{mg}$ per $100 \mathrm{ml}$ of liver water). Thus, it must be concluded that the lactate recovered was formed during incubation from precursors in the liver slices, and it appears likely that it arose from liver glycogen. No data are available on lactate production during incubation with glucagon.

In vitro incubation of liver slices was also performed in Patient 6. In this case, however, no effect of glucagon could be demonstrated. The initial glycogen concentration was $71 \mathrm{mg}$ per g (individual specimens, 72 and 69). After 1 hour of incubation in Krebs-Ringer phosphate buffer, the glycogen concentration was $65 \mathrm{mg}$ per $\mathrm{g}$ (specimens $68,60,70,58,68$ ). After incubation with glucagon, it was $63 \mathrm{mg}$ per $\mathrm{g}$ (specimens 61, 64, $55,72)$. Both in the control and the glucagon incubations, lactate was the principal metabolite recovered. Initial concentrations of glucose and lactate in the liver slices were 0.7 and $0.9 \mathrm{mg}$ per $\mathrm{g}$, respectively. An average of $1.5 \mathrm{mg}$ per $\mathrm{g}$ of glucose and $2.3 \mathrm{mg}$ per $\mathrm{g}$ of lactate appeared during incubation.

Blood lactate studies. Marked elevations of fasting blood lactate levels were observed in all six children. These are shown in Table III. The lowest value recorded was $30 \mathrm{mg}$ per $100 \mathrm{ml}$, observed once in Patient 2. On numerous other occasions, however, this child had higher levels, and her average fasting blood lactate concentration was $86 \mathrm{mg}$ per $100 \mathrm{ml}$. In contrast, among 52 consecutive determinations in healthy controls and patients with various other diseases, including both infants and adults, the highest value observed was $26 \mathrm{mg}$ per $100 \mathrm{ml}$ (average, 13).

Numerous determinations of blood lactate concentration were performed in five of the patients 
TABLE III

Levels of lactate in blood of fasting subjects

\begin{tabular}{cccc}
\hline & \multirow{2}{*}{$\begin{array}{c}\text { No. of } \\
\text { Petermin- } \\
\text { ations }\end{array}$} & \multicolumn{2}{c}{ Lactate } \\
\cline { 3 - 4 } & & Range & Mean \\
\hline & 18 & $40-128$ & 93 \\
2 & 27 & $30-130$ & 86 \\
3 & 8 & $55-85$ & 66 \\
4 & 1 & 69 & \\
5 & 10 & $72-122$ & 88 \\
6 & 4 & $52-130$ & 105 \\
43 healthy and & & & \\
$\begin{array}{l}\text { sick adults and } \\
\text { children without } \\
\text { glycogen disease }\end{array}$ & 52 & $3-26$ & 13 \\
& & & \\
\hline
\end{tabular}

at various time intervals after feedings, glucose infusions and other test situations. Although there were occasional anomalous findings, a consistent pattern emerged from these studies. The blood lactate level was high after periods of fasting and sustained hypoglycemia. It usually began to decline about an hour after hypoglycemia had been corrected. Glucose infusions usually produced greater and more rapid declines in lactate than did feedings. This fall in circulating lactate concentration often continued while the blood glucose level declined to hypoglycemic values, and the lowest blood lactate value was frequently obtained during a period of distinct hypoglycemia. However, after hypoglycemia had persisted for about an hour, a sharp rise in blood lactate concentration uniformly occurred. Figures 2 and 3 show blood glucose and lactate curves in association with glucose infusion or feeding. Figure 2 demonstrates reduction of lactate to normal levels after 3 hours of glucose infusion. The drop in lactate shown in Figure 3 was more rapid than that observed in most of these children after feedings; lactate rebound after 1 to 2 hours of hypoglycemia is well demonstrated.

The possibility was considered that endogenous epinephrine release secondary to hypoglycemia, and resultant glycogenolysis in muscle, might account for a major portion of the elevation in fasting lactate. In order to assess the contribution of this mechanism, epinephrine was administered to two patients at a time when their blood lactate levels were relatively low. It was reasoned that if endogenous epinephrine release played a dominant role in the production of the fasting hyper-

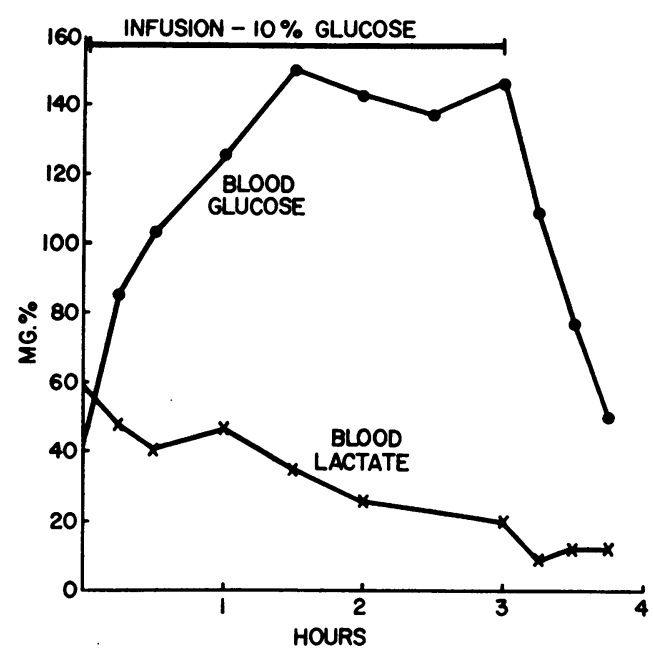

Fig. 2. Response of the blood lactate level to GLucose infusion. Patient 2 (S.J.). Glucose infusion, $0.5 \mathrm{~g}$ per $\mathrm{kg}$ per hour, was administered after an overnight fast.

lactacidemia, administration of exogenous epinephrine should be able to reproduce this finding. Accordingly, after a suitable overnight fast, these children were given an infusion of 10 per cent glucose. After 3 hours of glucose infusion, which resulted in a substantial drop in lactate level, each child received a subcutaneous injection of epinephrine, $0.03 \mathrm{mg}$ per $\mathrm{kg}$. In Patient 1 , the glucose infusion was continued; in Patient 2 , the infusion was terminated at the time of epinephrine injection. The blood lactate values before and after

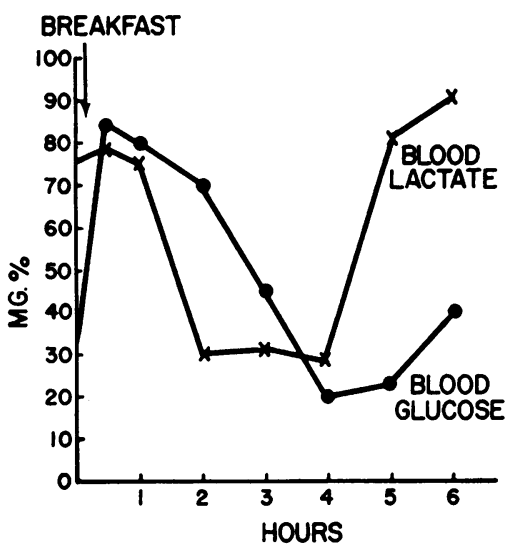

Fig. 3. Response of the blood lactate level to a FEEding. Patient 3 (Jay F.). Overnight fast. Initial values, just before breakfast (fruit juice, eggs, milk, and bread; protein $20 \mathrm{~g}$, fat $20 \mathrm{~g}$, carbohydrate $60 \mathrm{~g}$; calories $500)$. 
TAISLE IV

Effect of epinephrine on blood lactate levels of two patients

\begin{tabular}{|c|c|c|c|}
\hline & \multirow[b]{2}{*}{ Schedule } & \multicolumn{2}{|c|}{ Lactate } \\
\hline & & $\begin{array}{c}\text { Patient } \\
1\end{array}$ & $\underset{2}{\text { Patient }}$ \\
\hline & & \multicolumn{2}{|c|}{$\mathrm{mg} / 100 \mathrm{ml}$} \\
\hline \multirow{7}{*}{$\begin{array}{l}0 \mathrm{hr} \\
0-3 \mathrm{hr} \\
3 \mathrm{hr}\end{array}$} & Fasting & 94 & 108 \\
\hline & Glucose infusion, $0.5 \mathrm{~g} / \mathrm{kg} / \mathrm{hr}$ & & \\
\hline & $\begin{array}{l}\text { Just before ephinephrine } \\
\text { injection, } 0.03 \mathrm{mg} / \mathrm{kg}\end{array}$ & 47 & 38 \\
\hline & $15 \mathrm{~min}$ after epinephrine & & 52 \\
\hline & $30 \mathrm{~min}$ after epinephrine & 38 & 47 \\
\hline & $45 \mathrm{~min}$ after epinephrine & & 43 \\
\hline & $60 \mathrm{~min}$ after epinephrine & 47 & 43 \\
\hline
\end{tabular}

epinephrine injection are shown in Table IV. There was no rise in Patient 1 and a modest rise in Patient 2. These results were consistent with the muscle biopsy findings previously obtained (Table I) ; Patient 1 had an unusually low level of muscle glycogen, while Patient 2 had a normal muscle glycogen concentration. Although the possibility that these children may be unusually resistant to the metabolic effects of exogenous epinephrine cannot be exclucled, this experiment indicates that epinephrine release plays, at best, a relatively minor role in the production of the very high blood lactate levels described above. In contrast, when these children were given injections of glucagon under similar circumstances (see below), striking increases in lactate were always observed.

In vivo effects of glucagon. After the demonstration of an in vitro glucagon effect in Patient 1 , clinical studies with this agent were performed in all six children. Injections of glucagon produced major rises of blood lactate concentration in all experiments. Figure 4 shows the responses of these patients to intramuscular injection of 1.0 to $2.0 \mathrm{mg}$ of glucagon $(0.1 \mathrm{mg}$ per $\mathrm{kg}$ ) during the fasting state. For comparison, the responses of four normal children of similar weights are shown. A striking difference between the two groups was observed. The normal children had sharp rises in blood glucose levels, but little change in circulating lactate. The patients with glycogen disease, on the other hand, showed sharp increases in lactate and abnormally small rises in glucose concentration. The blood lactate curves among these patients resembled the blood glucose curves of the controls, though the absolute rises were smaller.
Table $\mathrm{V}$ lists the average changes in blood glucose and lactate values during the first 30 and $60 \mathrm{~min}$ utes of glucagon action among the six patients and the controls. Although there was variation among the patients, the pattern for each patient was a consistent one. For example, Patient 1 showed no rise or only a slight rise in the blood glucose level after glucagon injection. On the other hand, Patients 2 and 3 always showed some increase in the blood glucose level, although it was not nearly so rapid nor so great as that seen among the controls.

The effect of glucagon was also examined at various intervals after feeding or glucose infusion in five of the patients. Sharp rises in the blood lactate level were obtained under all circumstances. The effect of glucagon was more dramatic if it was injected at a time when the blood lactate level was relatively "low." For example, Patient 6 had a rise in lactate of only $20 \mathrm{mg}$ per $100 \mathrm{ml}$ when the initial level was $122 \mathrm{mg}$ per 100 $\mathrm{ml}$ (Figure 4, Table V). On another occasion, glucagon was given when the blood lactate level was $57 \mathrm{mg}$ per $100 \mathrm{ml}$, after feeding. The lactate rose to $113 \mathrm{mg}$ per $100 \mathrm{ml}$ in 30 minutes. On a third occasion, when the initial lactate concentration was $19 \mathrm{mg}$ per $100 \mathrm{ml}$, an increase to $119 \mathrm{mg}$ per $100 \mathrm{ml}$ was observed 1 hour after glucagon injection. Similar results were obtained in the other children.

Since doses of epinephrine presumably sufficient to induce glycogenolysis in muscle failed to reproduce the observed elevations in lactate (Table IV), and since glucagon exerts little or no effect on muscle, it appeared likely that the liver was

TABLE V

Mean changes in fasting blood glucose and lactate levels after glucagon injection (patients and controls)

\begin{tabular}{|c|c|c|c|c|c|}
\hline \multirow[b]{2}{*}{ Patient } & \multirow[b]{2}{*}{$\begin{array}{l}\text { No. of } \\
\text { studies }\end{array}$} & \multicolumn{2}{|c|}{$\begin{array}{l}\text { Increase in } \\
\text { glucose }\end{array}$} & \multicolumn{2}{|c|}{$\begin{array}{l}\text { Increase in } \\
\text { lactate }\end{array}$} \\
\hline & & $\begin{array}{l}0-30 \\
\min \end{array}$ & $\begin{array}{c}0-60 \\
\min \end{array}$ & $\begin{array}{c}0-30 \\
\min \end{array}$ & $\begin{array}{l}0-60 \\
\min \end{array}$ \\
\hline & & \multicolumn{2}{|c|}{$m g / 100 \mathrm{ml}$} & \multicolumn{2}{|c|}{$\mathrm{mg} / 100 \mathrm{ml}$} \\
\hline $\begin{array}{l}1 \\
2 \\
3 \\
4 \\
5 \\
6\end{array}$ & $\begin{array}{l}2 \\
3 \\
3 \\
1 \\
1 \\
1\end{array}$ & $\begin{array}{l}1 \\
15 \\
18 \\
13 \\
6 \\
4\end{array}$ & $\begin{array}{r}9 \\
30 \\
36 \\
35 \\
6 \\
5\end{array}$ & $\begin{array}{l}42 \\
36 \\
54 \\
64 \\
35 \\
20\end{array}$ & $\begin{array}{l}87 \\
52 \\
55 \\
45 \\
31 \\
13\end{array}$ \\
\hline \multicolumn{2}{|c|}{ Average, Patients 1-6 } & 10 & 20 & 42 & 47 \\
\hline \multicolumn{2}{|c|}{$\begin{array}{l}\text { Average, } 4 \text { normal } \\
\text { children }\end{array}$} & 86 & 91 & 3 & 2 \\
\hline
\end{tabular}



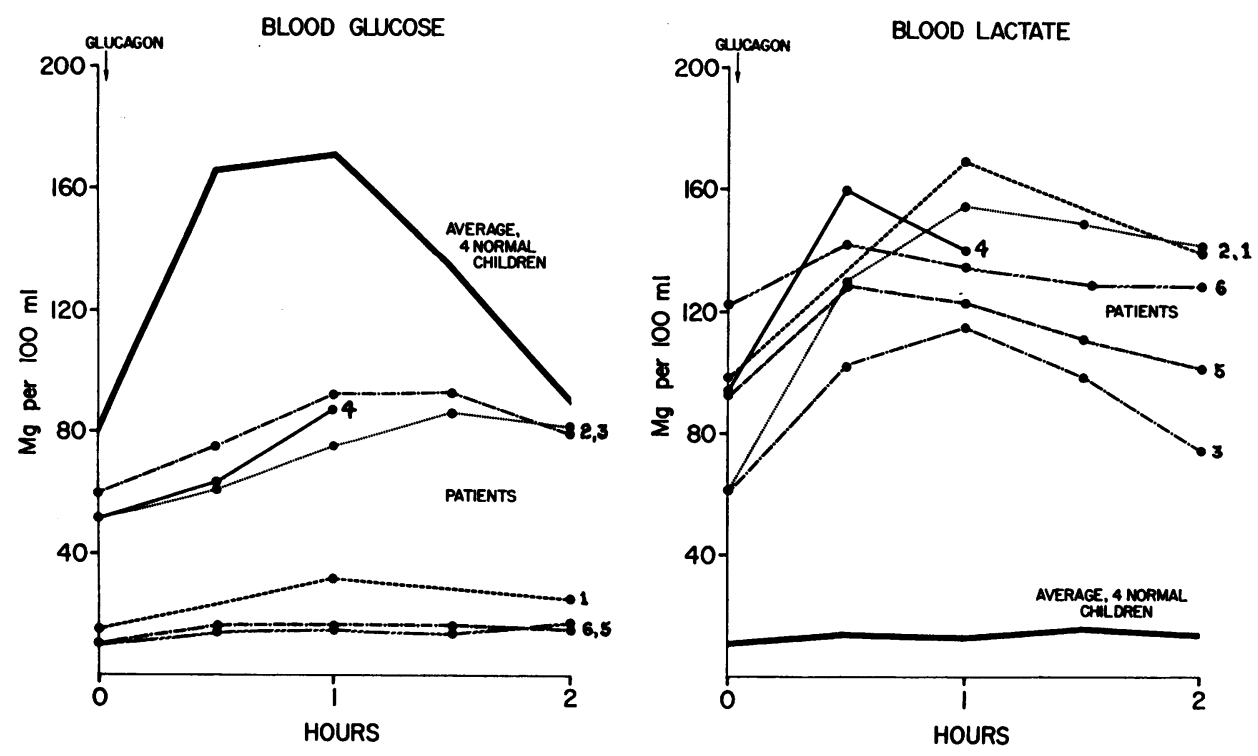

Fig. 4. EfFect of glucagon injection on the blood glucose and LaCTATE LEVELS OF PATIENTS AND CONTROLS. The numbers to the right of individual curves identify the patients.

the source of the excess circulating lactate. We attempted to confirm this by an experiment based on the report of Mason and Andersen (21), who found that arterial lactate was higher than venous lactate in a child with glycogen disease. In normal individuals, in whom muscle is a principal source of circulating lactate, the concentration of this metabolite is higher in venous than in arterial blood. Venous (medial cubital vein) and capillary blood samples were obtained in Patient 3 before and after glucagon administration. The lactate concentration rose sharply after glucagon injection, as in Figure 4. However, we did not observe a significant capillary-venous lactate difference either prior to or 30 minutes after glucagon injection. This indicates that muscle was not contributing lactate to the circulation, but does not constitute as striking evidence for the hepatic origin of the lactate as does the observation of Mason and Andersen.

The acute effect on liver size of relatively large doses of glucagon was studied in Patients 1, 2, 3, 5 , and 6. These children received 1 to $2 \mathrm{mg}$ of glucagon per hour for 4 hours, by intravenous infusion. A decrease in liver size was observed in all. This became apparent after the first hour and was maximal after 2 to 3 hours, at which time liver margins were 2 to $4 \mathrm{~cm}$ above the initial levels in Patients 1,2 and 3, and 1 to $2 \mathrm{~cm}$ above in Patients 5 and 6. Moderate to severe side effects were seen at this dose range, however. All five children developed restlessness and tachypnea and one vomited during the infusion. The clinical impression of acidosis was confirmed by determination of $\mathrm{pH}$ and bicarbonate content of blood in one patient. Distinct but relatively small changes in liver size were sometimes also observed after single subcutaneous injections of 1.0 to $1.5 \mathrm{mg}$ of glucagon. These doses produced few or no side effects.

\section{DISCUSSION}

The patients discussed herein were heterogeneous with respect to hepatic enzyme assay. They include two "classic" cases of glucose-6-phosphate deficiency, one case without a demonstrated enzymatic defect, perhaps similar to that reported by Hers (11), and one case with a previously undescribed enzymatic pattern-a deficiency in both phosphorylase and glucose-6-phosphatase. A detailed discussion of the significance of these enzyme patterns and of the subclassification of "von Gierke's disease" is beyond the scope of this paper. It must be emphasized, however, that these children form a homogeneous group in other respects. They had greatly enlarged livers containing excess glycogen; fasting hypoglycemia, acidosis, and ketosis; hyperlipemia, and delayed growth. 
Neither glucagon nor epinephrine evoked a hyperglycemic response. Spontaneous in vitro breakdown of glycogen to glucose was defective in the patients in whom this was studied. They had similar metabolic abnormalities and similar responses to glucagon. Thus, it seems appropriate to consider them together despite the differences in hepatic enzyme patterns.

Unequivocal stimulation of glycogenolysis by glucagon was demonstrated during in vitro incubation of liver slices in Patient 1. The principal end-product of this glycogenolysis was not glucose; indirect evidence suggests that it was lactate. In all six patients of this group, glucagon administration was followed by marked rises in blood lactate concentration. These increases in lactate resembled the increases in blood glucose concentration following the administration of glucagon to normal children. Comparison of capillary and venous lactate levels in one case indicated that the increment in lactate did not come from muscle. In all five children given glucagon infusions, an acute decrease in liver size was observed. Taken together, these findings suggest strongly that glucagon exerted its usual glycogenolytic effect on the liver in these cases, but that the principal endproduct of glycogen breakdown was lactate rather than glucose. The failure to demonstrate a glucagon response in vitro in Patient 6 is disturbing and, so far, unexplained. However, this child's clinical behavior and in viz'o response to glucagon was similar to that of Patient 1, where an effect on liver slices was demonstrated.

Normally, the blood lactate level is low in the fasting state and rises after a carbohydrate load (22). The fasting venous lactate concentration is higher than the arterial concentration, as muscle is a principal source of this metabolite, while the liver withdraws it from the circulation. In our patients, however, the blood lactate level was highest during fasting and decreased after feeding or glucose infusion. Muscle was not a major source of lactate. This "paradoxical" behavior is readily explained by the hypothesis that hepatic glycogenolysis was the principal source of circulating lactate in these cases. In the fasting state, hypoglycemia developed, hepatic glycogenolysis was stimulated, and the blood lactate level rose. After feeding or glucose infusion, hepatic glycogenolysis ceased, glycogen deposition supervened, and the blood lactate level fell. Glucagon produced sharp increases in blood lactate concentration under all circumstances by inducing rapid hepatic glycogenolysis.

Our conclusion that glucagon may induce hepatic glycogenolysis in some children with liver glycogen disease, just as it does in normal children, is not really in conflict with the findings of other investigators. A glucagon effect was looked for as early as 1932 by van Creveld (23), who administered an intravenous injection of insulin containing the "hyperglycemic factor" to a child with the disease. However, van Creveld examined only the response of the blood glucose level to such injection. Iater investigators similarly failed to consider the possibility that some other metabolite might be the end-product of glycogenolysis. However, our observation of a decrease in liver size during glucagon administration may not be unique. Gitzelmann (24) observed a reduction in liver size, comparable with that reported here, in a child thought to have a mild form of liver glycogen disease. He administered smaller doses over a longer period of time, and avoided the side effects we observed with intravenous infusions.

Most reports on liver glycogen disease do not include data on blood lactate levels. However, some authors have recorded strikingly increased fasting blood lactate values in this disorder (21, $25,26)$. Mason and Sly (25) observed, as we have, that the blood lactate level was markedly elevated during periods of prolonged hypoglycemia and that it fell toward normal values when the blood glucose level was maintained by frequent administration of glucose. Mason and Andersen (21) presented evidence that the liver, rather than muscle, was the source of the excess lactate during fasting. Excessive production of lactic acid may be largely responsible for the fasting acidosis in some cases of this disease $(21,26)$.

Confirmation of the points made above has recently appeared in an abstract by Howell, Ashton and Wyngaarden (27). These authors studied three siblings with liver glycogen disease, one of whom was subjected to liver biopsy and found to have a deficiency of hepatic glucose-6-phosphatase. All had high fasting blood lactate levels, comparable with those reported here. Glucagon infusions resulted in rapid and striking rises of blood lactate, but only slow increases in blood glucose. Liver 

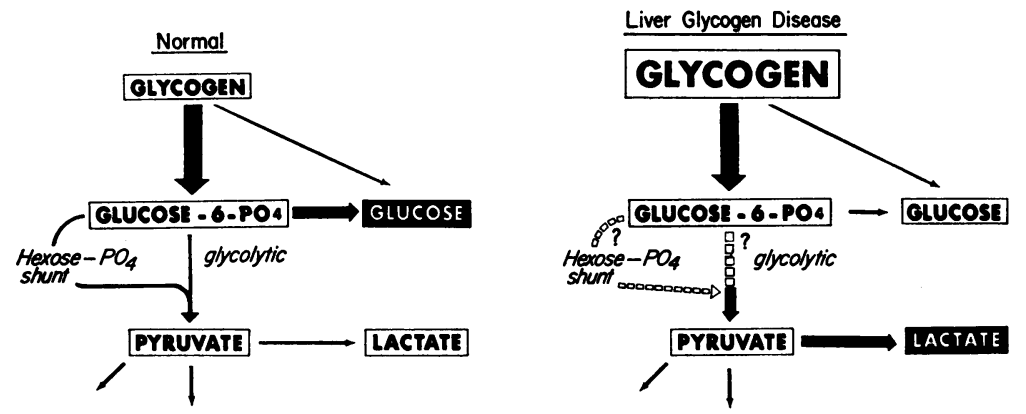

Fig. 5. Schematic Representation of liver glyCogen bReakdown in Patients 1-6, as compared with NoRmal individuals. Normally, glucose is the principal product of hepatic glycogenolysis. In these patients, lactic acid was the principal product.

slices incubated with glucagon showed appreciable glycogen breakdown and lactate production. The lactate concentration was higher in peripheral arterial than in venous blood, indicating that muscle was withdrawing, rather than contributing lactate to the circulation.

The phenomena discussed above are not seen in all cases of liver glycogen disease, however. Lindsay, Ross and Wigglesworth (28) reported a child whose fasting blood lactate level was only $25 \mathrm{mg}$ per $100 \mathrm{ml}$. In two cases, van Creveld (23) performed blood lactate determinations; his report does not give the actual values but it may be assumed from the context that they were not remarkable. In one proven case of liver glycogen disease with glucose-6-phosphatase deficiency, recently brought under study, we have found a normal fasting blood lactate level, which did not rise after glucagon administration. No decrease in liver size was observed when this child was given a glucagon infusion. Thus, the findings described in this paper apply only to certain cases of this puzzling disorder.

Our explanation of the hyperlactacidemia in some cases of liver glycogen disease, and its amelioration by glucose, postulates spontaneous hepatic glycogenolysis in response to fasting hypoglycemia and shift toward glycogen deposition when the blood glucose level is raised-i.e., metabolic turnover of liver glycogen. This view was presented earlier by Mason and Sly. This is contradictory to the concept of storage of metabolically unavailable liver glycogen expressed by some authors and implied in the term "glycogen storage disease," used by many. On critical examination, however, the evidence against active metabolic turnover of glycogen in this disease proves to be largely inferential. Many observers have assumed that failure of the blood glucose to rise after administration of glucagon or epinephrine indicates that glycogenolysis did not occur. Such an assumption may be quite erroneous even when the pathways of glycogen breakdown are normal (29) and would certainly be erroneous if the end-product of glycogenolysis is lactate. The fact that glycogenolysis could occur in this disease, either through the glycolytic pathway or through the phosphogluconate pathway, was emphasized by Cori and Cori (30).

In the six patients forming the subject of this report, lactate replaced glucose as the major in vivo end-product of hepatic glycogenolysis. Assuming that as in the normal, glucose-6-phosphate is the intermediate from which the metabolic pathways diverge, the sequence of events in these cases might be represented as in Figure 5. The initial stage of glycogen breakdown proceeds much as in normal. Deviations from the normal occur in the metabolism of glucose-6-phosphate and subsequent compounds. No data are available on the relative importance of the hexose monophosphate shunt versus the glycolytic pathway; these are represented by interrupted lines. This scheme postulates quantitative, rather than qualitative, differences from the normal. However, our data do not rule out the possibility that aberrant metabolic pathways may exist in liver glycogen disease; nor 
(lo they define the basic etiologic mechanism for the various abnormalities in this disorder.

\section{SUM MARY}

Six children with liver glycogen disease had strikingly elevated fasting blood lactate levels. In all five so studied, the blood lactate concentration fell when hypoglycemia was corrected by feeding or glucose infusions. Rapid return to markedly abnormal blood lactate values was observed after hypoglycemia was allowed to recur. In all six children, glucagon injection resulted in little or no rise in blood glucose, but in prompt and large increases of blood lactate levels. Intravenous infusions of glucagon produced acute decreases of liver size in all the five patients so treated.

Glucagon stimulated glycogenolysis during in vitro incubation of liver slices obtained from one of these patients, but only traces of glucose appeared in the medium.

It is concluded that active breakdown of liver glycogen occurred in these patients in response to the stimulus of hypoglycemia, and that glucagon exerted its usual hepatic glycogenolytic effect. However, the principal end-product of liver glycogen breakdown, whether spontaneous or glucagoninduced, was lactic acid rather than glucose.

\section{ACKNOWLEDGMENT}

We are indebted to Dr. Theodore C. Jewett for his cooperation in performing liver biopsies and to the following physicians who referred the patients discussed in this paper: Dr. Harry W. Bain, Dr. Eunice B. Miles, Dr. Malcolm L. Peterson, Dr. George B. Rosenfeld and Dr. Lester Schiff.

\section{REFERENCES}

1. van Creveld, S. Glycogen disease. Medicine (Baltimore) 1939, 18, 1.

2. Bridge, E. M., and Holt, L. E., Jr. Glycogen storage disease. Observations on the pathologic physiology of two cases of the hepatic form of the disease. J. Pediat. 1945, 27, 299.

3. Illingworth, B., and Cori, G. T. Structure of glycogens and amylopectins. III. Normal and abnormal human glycogens. J. biol. Chem. 1952, 199, 653.

4. Schönheimer, R. Ueber eine eigenartige Störung des Kohlehydrat-Stoffwechsels. Z. physiol. Chem. 1929, 182, 148.

5. Mason, H. H., and Andersen, D. H. Glycogen disease. Amer. J. Dis. Child. 1941, 61, 795.
6. Unshelm, E. Die Glykogenkrankheit (zugleich cin Beitrag zur Frage des hepatogenen Infantilismus). Jb. Kinderheilk. 1932, 137, 257.

7. White, A., Handler, P., Smith, E. L., and Stetten, D., Jr. Principles of Biochemistry, 2nd ed. New York, McGraw-Hill, 1959, pp. 430-431.

8. Leloir, L. F., and Cardini, C. E. Biosynthesis of glycogen from uridine diphosphate glucose. J. Amer. chem. Soc. 1957, 79, 6340.

9. Cori, G. T. Biochemical aspects of glycogen deposition disease. Mod. Probl. Pädiat. 1958, 3, 344.

10. Hers, H. G. Etudes enzymatiques sur fragments hepatiques: Application à la classification des glycogenoses. Rev. int. Hépat. 1959, 9, 35.

11. Hers, H. G. Conference on Hereditary Metabolic Diseases, IX Internat. Congr. Pediatrics, Montreal, 1959. Unpublished.

12. Ellis, R. W. B., and Payne, W. W. Glycogen disease (Von Gierke's disease: Hepato (nephro) megalia glycogenica). Quart. J. Med. 1936, 5, 31.

13. Schulman, J. L., and Saturen, P. Glycogen storage disease of the liver. I. Clinical studies during the early neonatal period. Pediatrics 1954, 14, 632.

14. Koulischer, N., and Pickering, D. E. Glycogenstorage disease. A study on effect of sodium 1-thyroxine and glucagon. Amer. J. Dis. Child. 1956, 91, 103.

15. Lowe, C. U., Doray, B. H., Sokal, J. E., and Sarcione, E. J. Carbohydrate metabolism in glycogen storage disease and the mode of action of insulin. Mod. Probl. Pädiat. 1959, 4, 157.

16. Nelson, N. A photometric adaptation of the Somogyi method for the determination of glucose. J. biol. Chem. 1944, 153, 375.

17. Barker, S. B., and Summerson, W. H. Colorimetric determination of lactic acid in biological material. J. biol. Chem. 1941, 138, 535.

18. Horn, H. D., and Bruns, F. H. Quantitative Bestimmung von $\mathrm{L}(+)$-Milchsäure mit Milchsäuredehydrogenase. Biochim. biophys. Acta 1956, 21, 378.

19. Good, C. A., Kramer, H., and Somogyi, M. The determination of glycogen. J. biol. Chem. 1933, 100, 485.

20. Lowe, C. U., Sokal, J. E., Mosovitch, L. L., Doray, B. H., and Sarcione, E. J. Metabolic studies in liver glycogen disease. In preparation.

21. Mason, H. H., and Andersen, D. H. Glycogen disease of the liver (Von Gierke's disease) with hepatomata. Case report with metabolic studies. Pediatrics 1955, 16, 785.

22. White, A., Handler, P., Smith, E. L., and Stetten, D., Jr. Principles of Biochemistry, 2nd ed. New York, McGraw-Hill, 1959, p. 439.

23. van Creveld, $\mathrm{S}$. Investigations on glycogen disease. Arch. Dis. Childh. 1934, 9, 9.

24. Gitzelmann, R. Glukagonprobleme bei den Glykogenspeicherkrankheiten. Helv. paediat. Acta 1957, 12, 425 . 
25. Mason, H. H., and Sly, G. E. Blood lactic acid in liver glycogen diseasc. Proc. Soc. exp). Biol. (N. Y.) 1943, 53, 145.

26. Schwartz, R., Ashmore, J., and Renold, A. E. Galactose tolerance in glycogen storage disease. Peditrics 1957, 19, 585.

27. Howell, R. R., Ashton, D., and Wyngaarden, J. B. Lipid, carbohydrate and purine abnormalities in Von Gierke's disease (abstract). J. clin. Invest. 1960, 39, 997.
28. Lindsay, L. M., Ross, A., and Wigglesworth, F. W. Von Gierke's glycogen discasc. Ann. intern. Med. 1935, 9, 274.

29. Sokal, J. E., and Sarcione, E. J. Failure of blood glucose levels to reflect hepatic glycogenolysis; experiences with glucagon. Proc. Soc. exp. Biol. (N. Y.) $1958,98,879$.

30. Cori, G. T., and Cori, C. F. Glucose-6-phosphatase of the liver in glycogen storage disease. J. biol. Chem. 1952, 199, 661. 